\title{
Differential Effects of Some Ascorbates on Phaseolus vulgaris L. In Response to Salinity Stress
}

\author{
B.A. Hamed ${ }^{\#}$ and Hamada AbdElgawad \\ Department of Botany and Microbiology, Faculty of Science, Beni-Suef University, \\ Beni-Suef, Egypt.
}

\begin{abstract}
$\mathbf{T}$ HIS study aimed to investigate the differential impact of potassium (K) and calcium $(\mathrm{Ca})$ ascorbate on physiological and biochemical responses of Phaseolus vulgaris to salt stress. To understand these differential responses, Phaseolus vulgaris seeds were soaked in a single or mixture $(1: 1,1: 2$ and $2: 1)$ of K-ascorbate: Caascorbate and then subjected to salt stress $(100 \mathrm{mM})$. In general, salt stress reduced plant growth, inhibited photosynthesis, respiration and stomatal conductance and induced oxidative stress. The antioxidant defense system (e.g., total phenol, proline and antioxidant enzymes) increased as a consequence of salt stress. Ascorbate pretreatment generally reduced stress, in particular at the level of oxidative stress parameters, where it decreased lipid peroxidation. In contrast, the pretreatment of seeds with ascorbate mitigate salinity stress at the growth and oxidative stress levels. Comparing the two ascorbate salts it was found that during stress, Ca-ascorbate increased growth, photosynthesis and antioxidants more than $\mathrm{K}$-ascorbate. Where 1:2 (K-ascorbate: Ca-ascorbate) ratio showed the highest stress mitigation effect. These specific responses were also identified and supported by Principal Component Analysis (PCA).
\end{abstract}

Keywords: Ascorbic acid, Phaseolus vulgaris, Salinity, Photosynthesis, Transpiration, oxidative stress, Antioxidant.

\section{Introduction}

Environmental stress conditions, salinity and drought, have detrimental effects on plant growth and production (Ahuja et al., 2010 and Shahbaz et al., 2013). Salinity reduces seed germination, plant growth and flowering, that ultimately causing reduction of plant productivity (Kanwal et al., 2013). This reduction in plant growth could be attributed to inhibited photosynthetic processes and carbohydrate biosynthesis, reduced stomatal conductance, deceased water use efficiency and induced nutritional deficiency (Doganlar et al., 2010; Kaymakanova, 2012; Parihar et al., 2015 and Chokshi et al., 2017). Salinity impairs Ca uptake up by plants, possibly by displacing it from the cell membrane or in some way affecting membrane function (Lauchli, 1990 and Ramesh et al., 2004). Salt stress also induce alterations in plant metabolism and accumulation of reactive oxygen species (ROS), which have damaging effects on lipids, proteins and nucleic acids (Hussain et al., 2008 and Rahdari et al., 2012).
ROS production under stress is mainly attributed to increased photorespiration, $\beta$-oxidation of fatty acids and activity of the mitochondrial electron transport chain (Apel \& Hirt, 2004). On the other hand, stress conditions in plants induce defense systems, including enhanced antioxidant activities to minimize the damaging effects of the free radical (Mittler et al., 2004 and Sharma et al., 2012).

The allelopathic effect of ascorbate on plants growth has been extensively studied (Niakan \& Mazandrani, 2009 and Niakan et al., 2012). Ascorbate is an important antioxidant in plant and many literatures showed that it has an essential role in several physiological processes in plants, including growth, differentiation, and metabolism (Noctor \& Foyer, 1998 and Horemans et al., 2000). Ascorbate functions as a reductant for many free radicals because of its ability to donate electrons in a number of enzymatic and non-enzymatic reactions (Gill \& Tuteja, 2010). By ascorbate peroxidase, ascorbate detoxify the

\#Corresponding author email: badreldinahamed@yahoo.com, Phone:+201100860030, Fax:+202 0822334551 
$\mathrm{H}_{2} \mathrm{O}_{2}$ to water and oxygen and it is oxidized to monodehydroascorbate and dehydroascorbate radicals and this is usually the main product of ascorbate oxidation in biological systems (Smirnoff, 1996 and Noctor \& Foyer, 1998). Ascorbate can directly regenerate tocopherol from tocopheroxyl radicals and plays a role as a co-factor of violaxanthin de-epoxidase, and thus providing membrane protection and sustaining dissipation of excess excitation energy ( $\mathrm{Li} \& \mathrm{Jin}$, 2007 and Pourcel et al., 2007).

Ascorbate enhances plant tolerance to environmental stressors such as saline stress (Khan et al., 2011; Ejaz et al., 2012 and Cai et al., 2016). For instance, exogenous application of ascorbate generally reduced inhibitory effects of salt stress on net photosynthetic rate, pigments biosynthesis and membrane integrity (Al-Hakimi \& Hamada, 2011). In this context, Khafagy et al. (2009), Dehghan et al. (2011) and Azzedine et al. (2011) reported that ascorbate mitigated the inhibitory effect of salt stress on plant growth due to increased leaf area, improved chlorophyll and carotenoid contents, and enhanced antioxidant accumulation. One mechanism of this protection effect is the ability of ascorbate to reduce stressinduced levels of ROS and further induced anti-oxidant defense system (Beyer, 1994 and Horemans et al., 2000). Ascorbate affected many enzyme activities, minimizing the oxidative damage through synergic function with other antioxidants (Foyer \& Noctor, 2005), where it induced enhancement in growth of salt-stressed plants coupled with an increase in catalase, peroxidase and superoxide dismutase activities (Munir \& Aftab, 2011). Protective effect of ascorbate pre-treatment under control and/or stress conditions is also highly dependent on rate of ascorbate uptake by plant. Studies with K- and $\mathrm{Ca}$-ascorbate recorded that the effectiveness of ascorbic acid depended on its uptake into the leaf (Freebairn, 1963). However, differential effects K and $\mathrm{Ca}$ - ascorbate on plant growth and metabolism under stress are poorly studied.

Potassium $\left(\mathrm{K}^{+}\right)$and Calcium $\left(\mathrm{Ca}^{2+}\right)$ are essential macronutrients for plants involved in many physiological processes (White \& Brown, 2010). They play important roles in cell osmosis adjustment, stomatal opening regulation, photosynthesis enhancement, energy loss decreasing, and translocation and enhancement of sugars and starch (White \& Broadly, 2003 and Wang et al., 2013). Calcium and potassium ameliorate the adverse effects of salinity on plants (Gorham, 1993; Volkamar et al., 1998; Munns, 2002 and Amador et al. 2007).

Phaseolus vulgaris is one of the most important legume crops grown all over the world. It is used as food and fodder because it is rich in protein, carbohydrate, minerals, vitamins and fibers (Amanullah, 2010). The objective of this study was to evaluate the effect of different ascorbate $\mathrm{K}: \mathrm{Ca}$ ratio on the physiological and biochemical responses of Phaseolus vulgaris to salinity stress, and to determine the most effective ascorbate salt form and dose.

\section{Materials and Methods}

Bean (Phaseolus vulgaris L. cultivar Morgan) seeds were obtained from Legume Research Institute (LRI), Agricultural Research Center (ARC), Giza, Egypt.

The used soil of this investigation was a garden soil. It was a clay loam with organic carbon $0.91 \%$, total $\mathrm{N} 0.12 \%, \mathrm{C}$ : $\mathrm{N}$ ratio 8.3 , total $\mathrm{P} 0.072 \%$ and $\mathrm{CaCO}_{3} 3.4 \%$. The soil was air-dried then sieved through $2-\mathrm{mm}$ sieve for using.

A preliminary experiment was conducted to determine the sub lethal salinity dose (100 $\mathrm{mM} \mathrm{NaCl})$ and the optimum ascorbate dose $(0.5$ $\mathrm{mM}$ ) which were calculated by using vigour index (Elias et al., 2012). 0.5\% NaOCl (sodium hypochlorite) sterilized seeds were soaked in 0.5 $\mathrm{mM}$ ascorbic acid or $0.5 \mathrm{mM}$ potassium ascorbate and/or calcium ascorbate. K-ascorbate and $\mathrm{Ca}$ ascorbate solutions were applied separately or in a mixture $(1: 1,1: 2$ or $2: 1, \mathrm{~W} / \mathrm{W}$, respectively) for $24 \mathrm{~h}$. Seeds of control samples were soaked in distilled water. Pre-treated seeds were cultivated in pots $(40-\mathrm{cm}$ diameter $\times 50-\mathrm{cm}$ Height $)$ containing sandy soil. Plants were incubated in the Educational Plant Chamber (Model No., 846,8463, Lab-Line USA, the central lab of Community Collage, Al-Baha University, KSA). The growth conditions were maintained at $250 \mu \mathrm{mol}$ PAR m-2 $\mathrm{s}-1,12 / 12 \mathrm{~h}$ day/night photoperiod, $22 \pm 0.5^{\circ} \mathrm{C}$ air temperature. Unstressed plants were irrigated with $50 \%$ modified Hoagland solution as described by Hoagland \& Arnon (1950) while stressed plants were irrigated with $50 \%$ modified Hoagland solution containing $100 \mathrm{mM} \mathrm{NaCl}$. To avoid salt accumulation, irrigation was done by using excess solution to wash accumulated salts (Bar-Tal et al., 1991). After 21-days seedlings were harvested and subjected to the different analyses. 
Dry weight, fresh weight, $\%$ of seed germination, shoots and root length, shoot/root ratio and seedling leaf area (LA) were measured.

The measurement of net photosynthetic rate $(\mathrm{PN})$, transpiration rate $(\mathrm{E})$ and stomatal conductance (gs) were measured using the ultra compact portable photosynthetic system model (LCi-SD) produced by ADC-Biosynthetic Ltd, Hoddeston, UK.

Both ofleafosmotic potential $\left(\Psi_{\mathrm{s}}\right)$ and leafturgor potential $(\Psi \pi)$ were measured using osmometer model 2020 produced by Advanced Instrument, Ltd, USA, according to the method described by Rekika et al. (1988), while relative water content (RWC) was determined by application the method described by Yamasaki \& Dillenburg (1999).

Malondialdehyde (MDA) was estimated by application the method of Health \& Packer (1968).

Soluble sugar and total carbohydrates were determined by the method of Naguib (1964). Proline and glycine betaine were estimated by the method of Singh et al. (1973) and Grieve \& Grttan (1983), respectively. Free amino acids were measured following the methods of Lee \& Takahashi (1966) and total $\mathrm{N}$ was determined by the by the method of Naguib (1969).

Phenolic compounds were extracted by applying the method of Jindal \& Singh (1975) and determined as described in AOAC (1990). Ascorbic acid (As A) was measured following the method of Kamisha et al. (2009) and glutathione (GTH) was measured using the procedure described by Kampfenkel et al. (1995).

Antioxidant enzymes were extracted from frozen bean seedlings according to the method of Shann \& Blum (1987). Superoxide dismutase activity (SOD, EC: 1.15.1.1) was determined by measuring the inhibition of the auto-oxidation of pyrogallol using the method of Marklund \& Marklund (1974). Catalase (CAT, EC: 1.11.1.6) activity was assayed following the method of $\mathrm{Xu}$ et al. (1997). Ascorbate peroxidase (APX, EC: 1.11.1.1) and ascorbic acid oxidase (ASO, EC: 1.10.3.3) activities were assayed by the method reported by Cao et al. (2004) and Maxwell \& Batman (1967) respectively. Phenol peroxidase (GPX, EC: 1.11.1.7) activity was assayed as described by Bergmeyer et al. (1974) while polyphenol oxidase (POX, EC: 1.10.3.1) activity was determined according to the method described by Kar \& Mishra (1976). Total soluble protein was determined by method of Lowry et al. (1951).

\section{Statistical analysis}

Results were analyzed by one-way ANOVA, using SPSS 20.0 statistical software (SPSS Inc., Chicago, IL, USA), and significant differences between the means were determined using the Duncan test $(\mathrm{P}<0.05) \quad(\mathrm{n}=4)$. Pearson correlation and Principal Component Analysis (PCA) were performed by XLSTAT 2010 (http://www.xlstat. com).

\section{Results and Discussion}

Ascorbate, $K$ and $C a$ contents in soaked seed

Soaking of Phaseolus vulgaris in different ratios of ascorbate- $\mathrm{K}$ and/or Ca caused increases in ascorbate, $\mathrm{K}$ and $\mathrm{Ca}$ contents (Table 1). The highest contents of ascorbate and calcium were recorded for seeds soaked in 1:2 (K-ascorbate: Ca-ascorbate) solution, while the highest content of potassium was recorded for seeds soaked in 1:0 (K-ascorbate:Ca-ascorbate) solutions. The increases in ascorbate and $\mathrm{Ca}$ contents in seeds could have a role in seed germination and growth; whereas high ascorbate and mineral availability is known to induce amylase activity and carbohydrate metabolism (Itoi \& Lopaschuk, 1996; Davey et al., 2000 and Abdul-Jaleel et al., 2008).

Ascorbate pre-treatment reduced salt stress impact

Salt stress inhibited seed germination and seedling growth (Table 2). Salinity in P. vulgaris reduced seed germination, shoot and root length, shoot:root ratio tissue dry weight. This negative impact could be attributed to water uptake restriction necessary for mobilization of nutrient required for germination and toxicity of the embryo by ions accumulation (Kaymakanova, 2012). Salinity also altered photosynthesis, transpiration rate, water use efficiency, stomatal conductance and relative water content (Table 3). Similarly, salinity is known to induce alterations in plant metabolism, including down regulation of photosynthetic and transpiration rates. Salinity also reduces stomatal and mesophyll conductance (Brugnoli \& Lauteri, 1991 and Parida $\&$ Das, 2005). Inhibitory effect of salinity on photosynthesis may be explained by induction of chlorophyll degrading and instability of pigment protein complexes (Rafique et al., 2011). This negative effect could also be attributed to reduced stomatal conductance (Brugnoli \& Lauteri, 1991 and Barhoumi et al., 2007). Where, decreased stomatal conductance leads to low availability of $\mathrm{CO}_{2}$ in mesophyll cells and therefore decreased photosynthetic efficiency (Kanwal et al., 2013). 
TABLE 1. The concentrations of As A, $\mathrm{K}^{+}$and $\mathrm{Ca}^{2+}$ in Phaseolus vulgaris seeds after $24 \mathrm{~h}$ of soaking in different ratios of ascorbate-K: $\mathrm{Ca}(\mu \mathrm{g} / \mathrm{g}$ DW). Data showed in the table represent Mean \pm SD superscripted with small letter; similar letters indicated that means were not different significantly at $\mathbf{p} \leq \mathbf{0 . 0 5}$ according to Duncan's multiple range tests.

\begin{tabular}{lccc}
\hline $\begin{array}{l}\text { Soaking solution (K:Ca, } \\
\text { W/W) }\end{array}$ & As A & $\mathbf{K}^{+}$ & $\mathbf{C a}^{2+}$ \\
\hline $\mathrm{H}_{2} \mathrm{O}$ & $0.00 \pm 0.00^{\mathrm{a}}$ & $0.00 \pm 0.00^{\mathrm{a}}$ & $0.00 \pm 0.00^{\mathrm{a}}$ \\
$\mathrm{AsA}$ & $93.2 \pm 1.27^{\mathrm{b}}$ & $0.00 \pm 0.00^{\mathrm{a}}$ & $0.00 \pm 0.00^{\mathrm{a}}$ \\
$(1: 0)$ & $92.9 \pm 1.27^{\mathrm{b}}$ & $20.6 \pm .28^{\mathrm{e}}$ & $0.00 \pm 0.00^{\mathrm{a}}$ \\
$(0: 1)$ & $180.7 \pm 2.55^{\mathrm{f}}$ & $0.00 \pm 0.00^{\mathrm{a}}$ & $20.6 \pm .28^{\mathrm{e}}$ \\
$(1: 1)$ & $134.8 \pm 1.84^{\mathrm{d}}$ & $10.9 \pm .14^{\mathrm{c}}$ & $10.4 \pm .14^{\mathrm{c}}$ \\
$(1: 2)$ & $152.8 \pm 2.12^{\mathrm{e}}$ & $6.8 \pm .14^{\mathrm{b}}$ & $13.9 \pm .14^{\mathrm{d}}$ \\
$(2: 1)$ & $122.3 \pm 1.7^{\mathrm{c}}$ & $13.4 \pm .14^{\mathrm{d}}$ & $6.9 \pm .14^{\mathrm{b}}$ \\
\hline
\end{tabular}

TABLE 2. Ascorbate- salinity interaction effects on \% of seed germination, root length $(\mathrm{cm} / \mathrm{root})$, shoot length $(\mathrm{cm} /$ shoot), shoo: root ratio and seedling dry matter $\left(\right.$ g plant $\left.^{-1}\right)$ of Phaseolus vulgaris seedlings. Data showed in the table represent Mean \pm SD superscripted with small letter; similar letters indicated that means were not different significantly at $\mathbf{p} \leq \mathbf{0 . 0 5}$ according to Duncan's multiple range tests.

\begin{tabular}{|c|c|c|c|c|c|c|c|}
\hline $\begin{array}{l}\text { Soaking } \\
\text { solution } \\
\text { (K:Ca, } \\
\text { W/W) }\end{array}$ & $\begin{array}{l}\text { Salinity } \\
\text { (mM) }\end{array}$ & $\begin{array}{c}\% \\
\text { germination }\end{array}$ & $\begin{array}{l}\text { Root } \\
\text { length }\end{array}$ & $\begin{array}{l}\text { Shoot } \\
\text { length }\end{array}$ & $\begin{array}{l}\text { Shoot: } \\
\text { root } \\
\text { ratio }\end{array}$ & Vigour index & Seedling DW \\
\hline \multirow[b]{2}{*}{ 00:00 } & 0 & $83.9 \pm 3.54^{\text {de }}$ & $6.5 \pm .28^{\mathrm{ef}}$ & $9.2 \pm .42^{\mathrm{e}}$ & 1.4 & $7719 \pm 328.1^{\mathrm{e}}$ & $.58 \pm .03^{\mathrm{e}}$ \\
\hline & 100 & $64.7 \pm 2.69^{\mathrm{a}}$ & $4.3 \pm .14^{\mathrm{a}}$ & $5.6 \pm .28^{\mathrm{a}}$ & 1.3 & $3623 \pm 154.15^{\mathrm{a}}$ & $.31 \pm .01^{\mathrm{a}}$ \\
\hline \multirow[b]{2}{*}{ As A } & 0 & $85.7 \pm 3.68^{\mathrm{def}}$ & $6.7 \pm .28 \mathrm{f}^{\mathrm{y}}$ & $9.6 \pm .42^{\mathrm{ef}}$ & 1.4 & $8227 \pm 349.31^{\text {ef }}$ & $.61 \pm .03^{\mathrm{ef}}$ \\
\hline & 100 & $65.5 \pm 2.83^{\mathrm{a}}$ & $4.5 \pm .14^{\mathrm{ab}}$ & $5.9 \pm .28^{\mathrm{ab}}$ & 1.3 & $3865 \pm 164.05^{\mathrm{ab}}$ & $.34 \pm .01^{\mathrm{ab}}$ \\
\hline \multirow[b]{2}{*}{ 01:00 } & 0 & $88.5 \pm 3.82^{\text {ef }}$ & $6.95 \pm .07^{\mathrm{fg}}$ & $9.8 \pm .42^{\mathrm{ef}}$ & 1.4 & $8673 \pm 367.7^{\mathrm{fg}}$ & $.62 \pm .03^{\mathrm{efg}}$ \\
\hline & 100 & $67.4 \pm 2.83^{\mathrm{ab}}$ & $4.7 \pm .14^{\mathrm{abc}}$ & $6.2 \pm .28^{\mathrm{ab}}$ & 1.3 & $4179 \pm 176.78^{\mathrm{ab}}$ & $.35 \pm .01^{\mathrm{ab}}$ \\
\hline \multirow[b]{2}{*}{ 00:01 } & 0 & $91.3 \pm 3.82^{\text {efg }}$ & $7.1 \pm .28^{\mathrm{gh}}$ & $10.2 \pm .42^{\mathrm{ef}}$ & 1.4 & $9313 \pm 394.57^{\mathrm{g}}$ & $.67 \pm .03^{\mathrm{gh}}$ \\
\hline & 100 & $71.2 \pm 2.97^{\mathrm{abc}}$ & $5.1 \pm .28^{\mathrm{cd}}$ & $6.7 \pm .28^{\mathrm{bc}}$ & 1.4 & $5119.5 \pm 292.04^{c}$ & $.39 \pm .01^{\mathrm{b}}$ \\
\hline \multirow[b]{2}{*}{ 01:01 } & 0 & $93.7 \pm 3.96^{\mathrm{fg}}$ & $7.6 \pm .28^{\mathrm{h}}$ & $10.9 \pm .42^{g}$ & 1.4 & $10894.5 \pm 536.69^{\mathrm{h}}$ & $.71 \pm .03^{\mathrm{h}}$ \\
\hline & 100 & $74.2 \pm 3.11^{\mathrm{bc}}$ & $5.4 \pm .28^{\mathrm{d}}$ & $7.4 \pm .28^{c}$ & 1.4 & $6004.5 \pm 492.85^{\mathrm{d}}$ & $.44 \pm .01^{\mathrm{c}}$ \\
\hline \multirow{4}{*}{ 01:02 } & 0 & $98.5 \pm 4.24^{\mathrm{g}}$ & $8.2 \pm .28^{\mathrm{i}}$ & $11.8 \pm .57^{\mathrm{h}}$ & 1.4 & $11623 \pm 493.56^{\mathrm{h}}$ & $.77 \pm .03^{\mathrm{i}}$ \\
\hline & 100 & $78.9 \pm 3.39^{\mathrm{cd}}$ & $6.1 \pm .28^{\mathrm{e}}$ & $8.3 \pm .28^{\mathrm{d}}$ & 1.4 & $6549.5 \pm 277.89^{d}$ & $.51 \pm .03^{\mathrm{d}}$ \\
\hline & 0 & $88.8 \pm 3.82^{\text {ef }}$ & $7.1 \pm .28^{\mathrm{gh}}$ & $9.9 \pm .42^{\text {ef }}$ & 1.4 & $8791 \pm 373.35^{\mathrm{g}}$ & $.64 \pm .03 \mathrm{f}^{y}$ \\
\hline & 100 & $69.3 \pm 2.97^{\mathrm{cd}}$ & $4.9 \pm .14^{\mathrm{bcd}}$ & $6.5 \pm .28^{\mathrm{b}}$ & 1.3 & $4505 \pm 190.92^{\mathrm{bc}}$ & $.38 \pm .01^{\mathrm{b}}$ \\
\hline
\end{tabular}




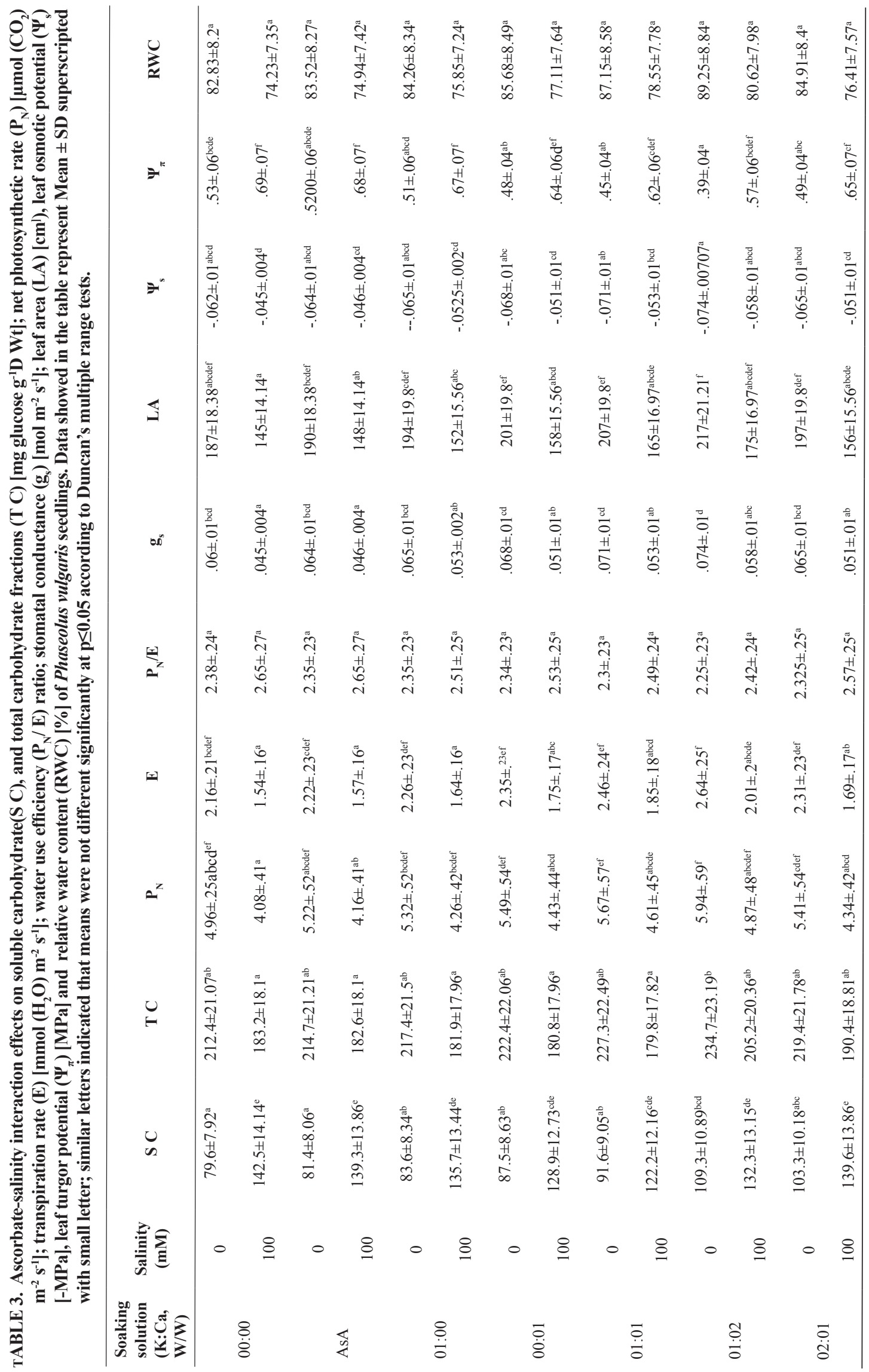

Egypt. J. Bot. 58, No.1(2017) 
It is obvious from many parameters that ascorbate pretreatment reduced the salinityinduced changes. This is apparent at the biomass (fresh weight, dry weight) level, but also at the level of photosynthesis $\left(\mathrm{g}_{\mathrm{s}}\right)$, transpiration and osmolyte induction (Tables 2 and 3 ). Growth induced effect of ascorbate pretreatment may be attributed to the fact that ascorbate protected meristematic cells in slat stressed plants by reducing ROS damage to essential proteins and/or nucleic acids (Khan et al., 2011) or by regulation cell division (Smirnoff, 1996). Ascorbate pretreatment also activate the biosynthesis of carbohydrates (Davey et al., 2000), which could participate in cell osmotic potential regulation (Shabala \& Cuin, 2008 and Abdul Hameed et al., 2015). Likewise, in this study as shown in Table 4, ascorbate pre-treatment increased growth and osmo-protectants accumulation under control and stress condition (soluble sugar, proline and glycine betaine). Both of Atak (2012) and Othman (2012) also ascribed the accumulation of these compounds to their regulating role of stomatal function. Moreover, ascorbates ameliorated the negative effects of salinity on photosynthesis. This stress mitigation impact may be due to the role of ascorbate as oxygen radicals and $\mathrm{H}_{2} \mathrm{O}_{2}$ scavenger (Asada, 1994) and/or its role against photoinactivation, since it is a factor of carotenoid de-epoxidation, (Siefermann \& Yamamoto, 1974).

Salinity increased induced damages in plant cells at the lipid levels (MDA) (Table 4). Increased malondialdehyde (MDA) content which is a result of lipid peroxidation and membrane deterioration may be attributed to the action of lipid peroxidase (Kumari et al., 2013 and Hassan et al., 2017). In addition, Ebrahimian \& Bybordi (2012) attributed this increment to ROS which cause membrane lipid peroxidation, reducing membrane fluidity and selectivity.

In parallel, salinity also induced increases in various antioxidant molecules, including membrane-associated tocopherols, proline and antioxidant enzymes (Hamed et al., 2014 and Yan et al. 2017). Similarly the present results indicated that the content of antioxidant metabolites (total antioxidant capacity, polyphenols and proline) and activity of SOD, CAT, ASO, APX, GPX and POD enzymes were increased (Tables 4 and 5). However, increases in lipid peroxidation are observed despite these increased antioxidant levels. Therefore, the ROS production exceeded even the induced defense capacity of the anti-oxidant systems to remove them. Also in other studies increases in the antioxidant system were insufficient to effectively protect the plant against ROS accumulation (Smirnoff, 1996; Van Breusegem \& Dat, 2006; Helena \& Carvalho, 2008 and Gill \& Tuteja, 2010).

In the present data it is found that, the ascorbate-induced changes in oxidative stress and anti-oxidant defense system are quite considerable; indicating that even seed pretreatment by ascorbate for a short period can alter salinity-induced changes. Interactions between ascorbate pre-treatment and salinity have also previously been observed. For example, increases in antioxidant enzyme activities in wheat plants were recorded after ascorbic acid application (Athar et al., 2009; Azevedo et al., 2011 and Cunha et al,. 2016). In the present study, ascorbate treated plant were more tolerant to salinity stress as compared to non treated plants. Similarly, Meloni \& Martinez (2009) indicated that plants containing higher concentrations of antioxidants showed more resistance to the oxidative damage caused by salt stress. In this context, Ebrahimian \& Bybordi (2012) discussed the ascorbate functions as a reductant agent for many free radicals, thereby minimizing the damage caused by oxidative stress. As an antioxidant, ascorbate will react with superoxide, hydrogen peroxide and/or the tocopheroxyl radical to form monodehydroascorbic acid and/ or dehydroascorbic acid. These oxidized forms are recycled back to ascorbic acid by monodehydroascorbate reductase and dehydroascorbate reductase using reducing equivalents from $\mathrm{NAD}(\mathrm{P}) \mathrm{H}$ or glutathione, respectively. The indirect role of ascorbate as an antioxidant is to regenerate membranebound antioxidants, such as $\alpha$-tocopherol, that scavenge peroxyl radicals and singlet oxygen species (Pourcel et al., 2007). Hence an increase in the activities of antioxidant enzymes of bean plants as observed during the present work is in line with these findings. 


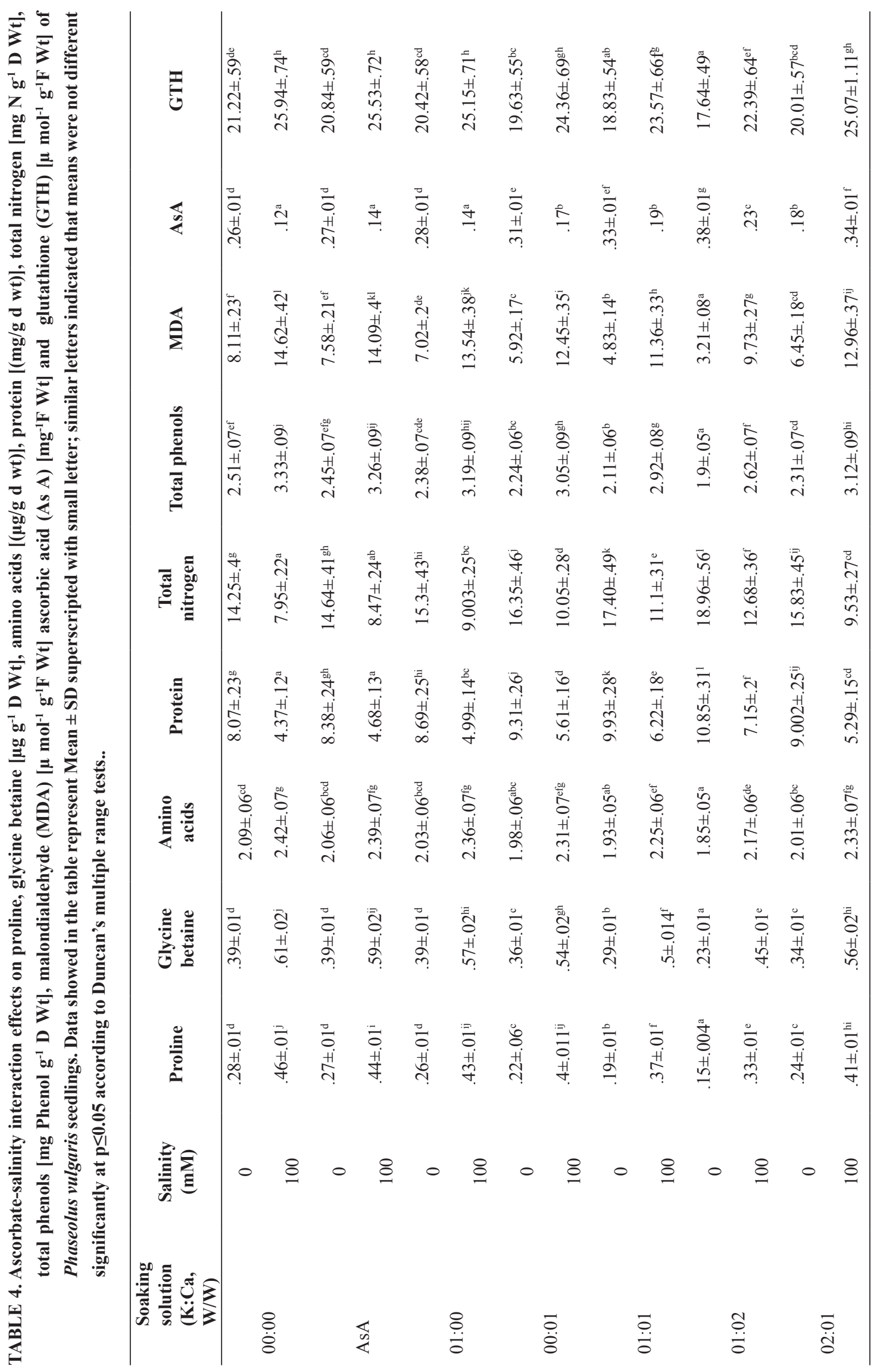

Egypt. J. Bot. 58, No.1(2017) 
TABLE 5. Ascorbate-salinity interaction effects on superoxide dismutase (SOD), catalase (CAT), ascorbic acid oxidase (ASO), ascorbate peroxidase (APX), phenol peroxidase (GPX) and polyphenol oxidase (POX) $\left[\mathrm{g}^{-1} \mathrm{~F} \mathrm{Wt}\right.$ min $\left.^{-1}\right]$ of Phaseolus vulgaris seedlings. Data showed in the table represent Mean $\pm \mathrm{SD}$ superscripted with small letter; similar letters indicated that means were not different significantly at $\mathbf{p} \leq \mathbf{0 . 0 5}$ according to Duncan's multiple range tests.

\begin{tabular}{|c|c|c|c|c|c|c|c|}
\hline $\begin{array}{l}\text { Soaking } \\
\text { solution } \\
\text { (K:Ca, } \\
\text { W/W) }\end{array}$ & $\begin{array}{c}\text { Salinity } \\
(\mathbf{m M})\end{array}$ & SOD & CAT & ASO & APX & GPX & POX \\
\hline \multirow[b]{2}{*}{ 00:00 } & 0 & $2.5 \pm .14^{\mathrm{de}}$ & $1.9 \pm .14^{\text {cde }}$ & $13.6 \pm .71^{\mathrm{bcd}}$ & $25.3 \pm 1.41^{\text {abcde }}$ & $2.36 \pm .13^{\mathrm{f}}$ & $2.71 \pm .16^{\mathrm{f}}$ \\
\hline & 100 & $3.7 \pm .14^{\mathrm{i}}$ & $2.6 \pm .14^{\mathrm{h}}$ & $16.9 \pm .99^{f}$ & $29.3 \pm 1.7^{f}$ & $5.19 \pm .3^{1}$ & $5.96 \pm .34^{1}$ \\
\hline \multirow[b]{2}{*}{ AsA } & 0 & $2.4 \pm .14^{\mathrm{cd}}$ & $1.8 \pm .14^{\mathrm{bcd}}$ & $13.4 \pm .71^{\mathrm{bc}}$ & $25.1 \pm 1.41^{\text {abcde }}$ & $2.13 \pm .13 \mathrm{e}^{\mathrm{f}}$ & $2.42 \pm .14^{\mathrm{ef}}$ \\
\hline & 100 & $3.6 \pm .14^{\mathrm{hi}}$ & $2.5 \pm .14^{\mathrm{gh}}$ & $16.6 \pm .99^{\mathrm{f}}$ & $28.9 \pm 1.7^{\mathrm{f}}$ & $4.94 \pm .28^{\mathrm{kl}}$ & $5.67 \pm .33^{\mathrm{kl}}$ \\
\hline \multirow[b]{2}{*}{ 01:00 } & 0 & $2.3 \pm .14^{\mathrm{cd}}$ & $1.8 \pm .14^{\mathrm{bcd}}$ & $13.1 \pm .71^{\mathrm{abc}}$ & $24.6 \pm 1.41^{\mathrm{abcd}}$ & $1.88 \pm .11^{\mathrm{de}}$ & $2.16 \pm .13^{\mathrm{de}}$ \\
\hline & 100 & $3.5 \pm .14^{\mathrm{hi}}$ & $2.5 \pm .14^{\mathrm{gh}}$ & $16.4 \pm .99^{\text {ef }}$ & $28.6 \pm 1.56^{\mathrm{ef}}$ & $4.72 \pm .27^{\mathrm{jk}}$ & $5.42 \pm .31^{\mathrm{jk}}$ \\
\hline \multirow[b]{2}{*}{ 00:01 } & 0 & $2.1 \pm .14^{\mathrm{bc}}$ & $1.6 \pm .14^{\mathrm{abc}}$ & $12.6 \pm .71^{\mathrm{ab}}$ & $24.1 \pm 1.41^{\mathrm{abc}}$ & $1.42 \pm .08^{\mathrm{c}}$ & $1.62 \pm .08^{c}$ \\
\hline & 100 & $3.3 \pm .14^{\mathrm{gh}}$ & $2.3 \pm .14^{\mathrm{fgh}}$ & $15.8 \pm .85^{\mathrm{ef}}$ & $28.1 \pm 1.56^{\mathrm{def}}$ & $4.25 \pm .24^{\mathrm{i}}$ & $4.88 \pm .28^{\mathrm{i}}$ \\
\hline \multirow[b]{2}{*}{ 01:01 } & 0 & $1.75 \pm .35^{\mathrm{ab}}$ & $1.5 \pm .14^{\mathrm{ab}}$ & $12.1 \pm .71^{\mathrm{ab}}$ & $23.3 \pm 1.27^{\mathrm{ab}}$ & $.93 \pm .06^{\mathrm{b}}$ & $1.07 \pm .06^{\mathrm{b}}$ \\
\hline & 100 & $3.1 \pm .14^{\mathrm{fg}}$ & $2.2 \pm .14^{\mathrm{efg}}$ & $15.3 \pm .85^{\mathrm{def}}$ & $27.3 \pm 1.56^{\text {cdef }}$ & $3.78 \pm .21^{\mathrm{h}}$ & $4.34 \pm .24^{\mathrm{h}}$ \\
\hline \multirow[b]{2}{*}{ 01:02 } & 0 & $1.6 \pm .14^{\mathrm{a}}$ & $1.3 \pm .14^{\mathrm{a}}$ & $11.2 \pm .57^{\mathrm{a}}$ & $22.3 \pm 1.27^{\mathrm{a}}$ & $.22 \pm .01^{\mathrm{a}}$ & $.27 \pm .01^{\mathrm{a}}$ \\
\hline & 100 & $2.8 \pm .14^{\mathrm{ef}}$ & $2 \pm .14 \mathrm{~d}^{\mathrm{ef}}$ & $14.6 \pm .85^{\mathrm{cde}}$ & $26.5 \pm 1.56^{\text {bddef }}$ & $3.06 \pm .17^{\mathrm{g}}$ & $3.52 \pm .2^{\mathrm{g}}$ \\
\hline \multirow{2}{*}{ 02:01 } & 0 & $2.2 \pm .14^{\mathrm{cd}}$ & $1.7 \pm .14^{\mathrm{bcd}}$ & $12.8 \pm .71^{\mathrm{abc}}$ & $24.3 \pm 1.41^{\mathrm{abc}}$ & $1.65 \pm .1^{\mathrm{cd}}$ & $1.89 \pm .11^{\mathrm{cd}}$ \\
\hline & 100 & $3.4 \pm .14^{\mathrm{ghi}}$ & $2.4 \pm .14^{\mathrm{gh}}$ & $16.1 \pm .85^{\mathrm{ef}}$ & $28.4 \pm 1.56^{\mathrm{ef}}$ & $4.49 \pm .25^{\mathrm{ij}}$ & $5.16 \pm .3^{\mathrm{ij}}$ \\
\hline
\end{tabular}

$K$ and Ca-ascorbate mixtures differently affect plant responses to salinity stress

The effect of different ascorbate on the stress responses showed $\mathrm{K} / \mathrm{Ca}$ salt-specificity. All ascorbate mixtures stimulated plant growth and photosynthetic processes and overcame the inhibition caused by salinity in Phaseolus vulgaris. The observed positive effect of $\mathrm{K}$ could be attributed to the fact that depressing the cytosol's water activity by higher accumulation of $\mathrm{Na}$ in vacuole during stress requires a coordinated increase in compatible solutes $(\mathrm{K})$ in the cytosol to balance out the osmotic pressure. Amtmann \& Rubio (2012) referred the role of $\mathrm{K}$ in osmotic adjustment to charge balance. They considered this mechanism as a mechanism type of ion homeostasis. Additionally, similarities between the physiochemical properties of $\mathrm{Na}$ and $\mathrm{K}$ could compete with $\mathrm{K}^{+}$for uptake sites at the plasma membrane (Prajapati \& Modi, 2012; Wang et al., 2013 and Kibria et al., 2017). Amtmann \& Rubio (2012) attributed the role of $\mathrm{K}^{+}$on photosynthesis to its counter on $\mathrm{H}^{+}$-fluxes and/or enhancing Rubisco enzyme responsible for $\mathrm{CO}_{2}$ fixation through $\mathrm{pH}$ regulation. $\mathrm{K}$ also has a controlling role its loading into the xylem most likely mediated the xylem hydraulic conductance that aided plants in maintaining cell turgor, stomatal aperture and gas exchange rates as part of stomatal activity (Wang et al., 2013 and Abdul Hameed et al., 2015). Also, Amtmann \& Rubio (2012) and Wang et al. (2013) attributed the effect of $\mathrm{K}^{+}$in the increment of carbohydrate to its role of the maintenance of high $\mathrm{pH}$ which accelerates sucrose loading and amino acids transportation which means finally more carbohydrate synthesis. 
However, as compared to $1: 0$ and $2: 1(\mathrm{~K}: \mathrm{Ca}$ ascorbate) ratios, $0: 1$ and $1: 2$ ( $\mathrm{K}: \mathrm{Ca}$ ascorbate) ratios showed the highest inductions in plant growth and photosynthesis (Table 2). Hepler (2005) attributed the alleviating effect of calcium to its regulatory and controlling roles for maintenance of plasma membrane, photoprotein and/or protein synthesizing enzymes. Ca controls stomatal activity by perturbation of $\left[\mathrm{Ca}^{2+}\right]_{\text {cyt }}$ in guard cells, White \& Broadly (2003) and Hepler (2005) reported that calcium retarded the loss of chlorophyll and protein suggesting that the ion could have a regulatory role in maintaining and controlling membrane structure and function of plastids. Alleviating role of calcium, also, may be due to its stimulating effect on amylase activity (Abdul-Jaleel et al., 2008) and/or its involving role in carbohydrate biosynthesis (Itoi \& Lopaschuk, 1996). It also regulates gene expression by binding to specific transcription factors which may be responsible for the more synthesized protein (White \& Broadly, 2003). On the other side, there was interaction between potassium and calcium, where higher $\mathrm{K}$ to $\mathrm{Ca}$ ratio $(2: 1, \mathrm{~K}: \mathrm{Ca}$ ascorbate) showed less effect as compared to equal $\mathrm{K}$ to $\mathrm{Ca}$ ratio (1:1, $\mathrm{K}: \mathrm{Ca}$ ascorbate). In agreement, Malvi (2011) indicated that the excessive amounts of potassium reduce uptake of calcium. Such reduction can be connected to the great similarity between them which causing their competition on both selective and non selective cation channels (White \& Broadly, 2003 and Malvi, 2011).

At the biochemical level, the reduction of lipid peroxidation by ascorbate was somewhat more pronounced in the case of $1: 1$ and $1: 2(\mathrm{~K}: \mathrm{Ca}$ ascorbate) ratios as compared to other ratios. This different $\mathrm{K}: \mathrm{Ca}$ ascorbate ratios separation was further supported by principal component analysis (PCA). This analysis was performed to display the maximum amount of variation in a data profile within a few principal components and to understand relations between variables. The plot depicts standardized scores along the first two components, together explaining 97.8\% of the data variability (Fig. 1). Ascorbate (K:Ca) treatments under control and salt stress conditions were separated mainly along PC1 $(90 \%$ of data variability). PC1 was heavily loaded on parameters related to growth, photosynthesis and antioxidants.

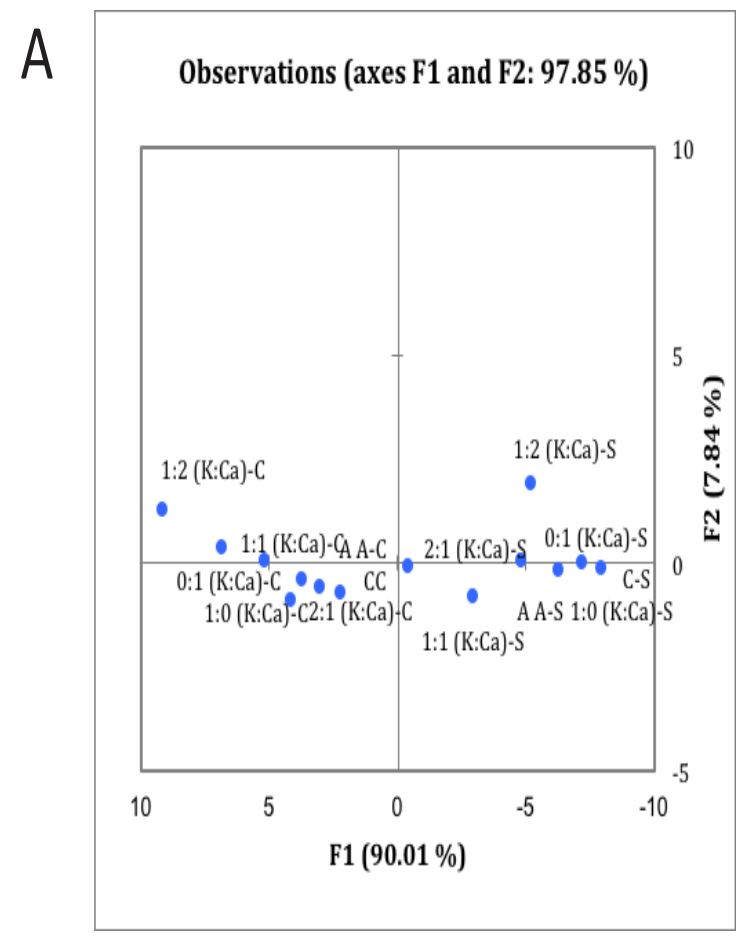

B

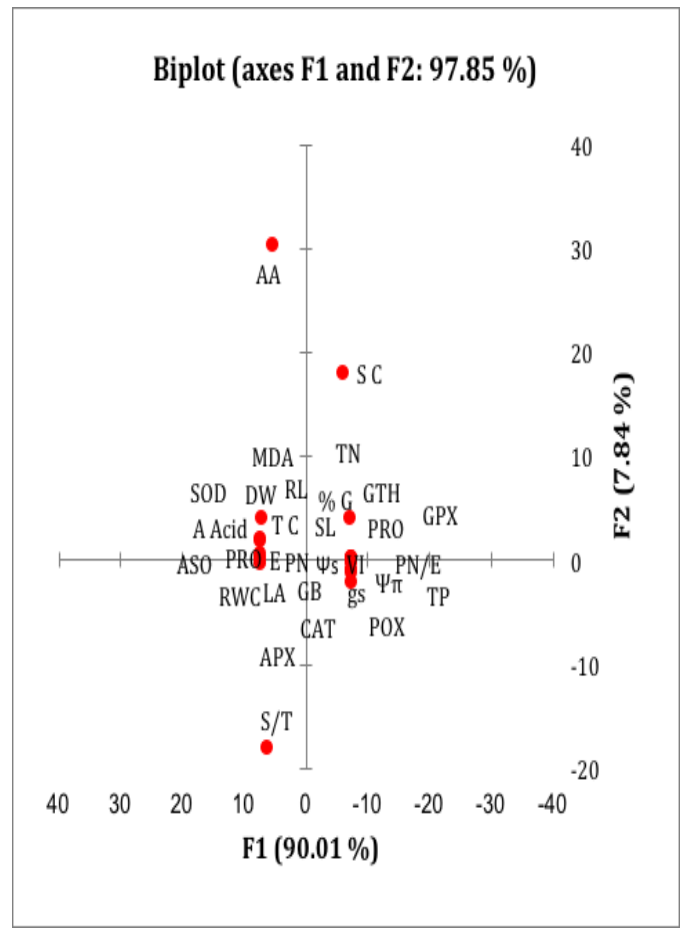

Fig. 1. Principal component analysis (PCA). (A) Biplot based on PC1 ('F1') and PC2) ('F2') from PCA of different ascorbate $(\mathrm{K}: \mathrm{Ca})$ ratios $(0: 0,1: 0,1: 1,2: 1$ and 1:2) under control and salt stress conditions. Percentages correspond to how much data variability is explained by the respective component. (B), Correlation circle showing a projection of the original variables in the principal components space PC1-PC2. 
Finally, this result can advise to apply a mixture of K-ascorbate:Ca-ascorbate $(1: 2, \mathrm{~W} / \mathrm{W})$ to improve the growth of Phaseolus vulgaris grown under either normal condition or under salinity stress

\section{References}

Abdul Hameed, Gulzar, S., Aziz, I., Hussain, T., Gul1, B. and Ajmal Khan, A. (2015) Effects of salinity and ascorbic acid on growth, water status and antioxidant system in a perennial halophyte. J. Plant Science, 1-11. AoB Plants. www.aobplants.oxfordjournals. org

Abdul-Jaleel, C., Gopi, R., Gomathinayagam, M. and Pannerselvamacta, R. (2008). Effects of calcium chloride on metabolism of salt-stressed. Dioscorea rotunata Botanica, 50(1), 63-67.

Ahuja, I., Vos, R.C.H.De., Bones, A.M., Hall, R.D. and de Vos, R.C.H. (2010) Plant molecular stress responses face climate change. Trends Plant Sci. 15, 664-674.

Al-Hakimi, A.M. and Hamada, A.M. (2011). Ascorbic acid, thiamine or salicylic acid induced changes in some physiological parameters in wheat grown under copper stress. Plant Protec. Sci. 47, 92-108.

Amador, B.M., Yamada, S., Yamaguchi, T., Puente, E.R., Serrano, N.A.V., Hernandez, J.L.G., Aguilar, R.L., Dieguez, E.T. and Garibay, A.N. (2007) Influence of calcium silicate on growth, physiological parameters and mineral nutrition in two legume species under salt stress. J. Agron. Crop Sci. 193, 413-421.

Amanullah, Jr. (2010) Common Bean (Phaseolus vulgaris $\mathrm{L}$.): The unexploited but the potential food legume crop in the Northern Khyber PakhtunkhwaPakistan. Publisher: Create Space Independent Publishing Platform ISBN-10,1456319116. ISBN13: 978-1456319113.

Amtmann, A. and Rubio, F. (2012) In: "Potassium in Plants" LS. John Wiley \& Sons, Ltd: Chichester. DOI: 10.1002/9780470015902.a0023737: pp. 1- 10.

AOAC (1990) Association of Official Analytical Chemists. "Official Methods of Analysis". 15 $5^{\text {th }}$ ed. pp.746. Washington D C.

Apel, K. and Hirt, H. (2004) Reactive oxygen species: Metabolism, oxidative stress, and signal transduction. Annul Review Plant Biolog. 55, 373-99.

Asada, K. (1994) Mechanisms for scavenging reactive molecules generated in chloroplasts under light stress. In: "Photoinhibition of Photosynthesis.
From Molecular Mechanisms to the Field". Baker N.R., Bowyer, J.R. (Ed.), pp.129-142. Oxford: Bios Scientific Publishers.

Atak, O.C.C. (2012) The effect of salt stress on antioxidative enzymes and proline content of two Turkish tobacco varieties. Turk. J. Biol. 36, 339-356.

Athar, H.R., Khan, A. and Ashraf, A. (2009) Inducing salt tolerance in wheat by exogenously applied ascorbic acid through different modes. J. Plant Nutr. 32, 1799-1817.

Azevedo, R.A., Carvalho, R.F. and Cia, M.C. (2011) Sugarcane under pressure: An overview of biochemical and physiological studies of abiotic stress. Trop Plant Biol. 4, 42-51.

Azzedine, F., Gherroucha, H. and Baka, M. (2011) Improvement of salt tolerance in durum wheat by ascorbic acid application. J. Stress Physiol. Biochem. 7, 27-37.

Barhoumi, Z., Djebali, W., Chaibi, W., Abdelly, Ch. and Smaoui, A. (2007) Salt impact on photosynthesis and ultrastructure of Aelurous littoralis. J. Plant. Res. 120, 529-537.

Bar-Tal, A., Feigenbaum, S. and Sparks, D.L. (1991) Potassium-salinity interactions in irrigated corn. Irrigation Sci. 12, 27-35.

Bergmeyer, H.U., Gaulehn, K. and Grassl, M. (1974) "Methods of Enzymatic Analysis" $2^{\text {nd }}$ ed., 1, pp. 495496. Academic Press, Newyork .

Beyer, R.E. (1994) The role of ascorbate in antioxidant protection of biomembranes, interaction with vitamin E, and coenzyme Q. Archives of Bioengineering. $J$. Bioenergetics and Biomembranes, 26, 349-358.

Brugnoli, E. and Lauteri, M. (1991) Effect of salinity on stomatal conductance, photosynthetic capacity and carbon isotope discrimination of salt tolerant (Gossypium hirsutum L.) and salt-sensitive (Phaseolus vulgaris L.) $\mathrm{C}_{3}$ non-halophytes. Plant Physiol. 95, 628-635.

Cai, X., Zhang, C., Shu, W., Ye, Z. and Li, H. (2016) The transcription factor 1 Dof 22 involved in ascorbate accumulation and salinity stress in tomato. Biochemical and Biophysical Research Communications, 474, 736-741.

Cao, X., Ma, L. Q. and Tu, C. (2004) Antioxidative responses to arsenic in the arsenic-hyperaccumulator Chinese barke fern (Pteris vittata L.). Environ. Pollu. 128, 317-325. 
Chokshi, K., Pancha, I., Ghosh, A. and Mishra, S. (2017) Salinity induced oxidative stress alters the physiological responses and improves the biofuel potential of green microalgae Acutodesmus dimorphus. Bioresource Technology, 244, 13761383.

Cunha, R.J., Neto, M.C.L., Carvalho, F.E.L., Marcio, O.C., Martins, M.O., Jardim-Messederc, D., MargisPinheiroc, M. and Silveiraa, J.A.G. (2016) Salinity and osmotic stress trigger different antioxidant responses related to cytosolic ascorbate peroxidase knockdown in rice roots. Environmental and Experimental Botany, 131, 58-67.

Davey, M.W., Montagu, M., Inze', D., Sanmartin, M., Kanellis, A., Smirnoff, N., Benzie, I.J.J., Strain, J.J., Favell, D. and Fletcher, H. (2000) Review: Plant L- ascorbic acid: Chemistry, function, metabolism, bioavailability and effects of processing. J. Sci. Food Agri. 80, 825-860.

Dehghan, G., Rezazadeh, L. and Habibi, G. (2011) Exogenous ascorbate improves antioxidant defense system and induces salinity tolerance in soybean seedlingsl, Acta Biologica Szegediensis, 55, 261-264.

Doganlar, Z. B., Demir, K., Basak, H. and Gul, I. (2010) Effects of salt stress on pigment and total soluble protein contents of the three different tomato cultivars. Afr. J. Agri. 5, 2056-2065.

Ebrahimian, E. and Bybordi, A. (2012) Effect of salinity, salicylic acid, silicium and ascorbic acid on lipid peroxidation, antioxidant enzyme activity and fatty acid content of sunflower. Afr. J. Agri. Res. 7, 36853694.

Ejaz, B., Sajid, Z. and Aftab, F. (2012). Effect of exogenous application of ascorbic acid on antioxidant enzyme activities, proline contents, and growth parameters of Saccharum spp. hybrid cv. HSF-240 under salt stress. Turk. J. Biol. 630-640.

Elias, S.E. Copeland, L.O., McDonald, M.B. and Baalbaki, R.Z. (2012) "Seed Testing: Principles and Practices". Michigan State University Press. ISBN10: 1611860393. ISBN-13,978-1611860399.

Foyer, C.H. and Noctor, G. (2005) Redox homeostasis and antioxidant signaling: A metabolic interface between stress perception and physiological responses. The Plant Cell, 17, 1866-1875.

Freebairn, T. (1963) Uptake and movement of 1-C14 ascorbic acid in bean plants. Plant Physiology, 16, $517-522$.
Gill, S. and Tuteja, N. (2010). Reactive oxygen species and antioxidant machinery in abiotic stress tolerance in crop plants. Plant Physiol. Biochem. 48, 909-930.

Gorham, J. (1993) Genetics and physiology of enhanced K/Na discrimination. In: "Genetic Aspects of Plant Mineral Nutrition". Randall, P., (Ed.), pp. 151159. Kluwer Academic Publishers, Dordrecht, Netherlands.

Grieve, C.M. and Grttan, S.R. (1983) Rapid assay for determination of water soluble quaternary ammonium compounds. Plant and Soil, 70, 303307.

Hamed, K.B., Chibani, F., Abdelly, C. and Magne, C. (2014) Growth, sodium uptake and antioxidant responses of coastal plants differing in their ecological status under increasing salinity. Biologia, 69, 193-201.

Hassan, Y.M., Hamed, B.A., Khodary, S.A. and Hamouda, O.H.I. (2017). Salt stress mitigation by seed priming with olive waste of Phaseolus vulgaris L. Nature and Science, 15(6). http://www. sciencepub.net/nature.

Health, R.L. and Packer, L. (1968) Photoperoxidation in isolated chloroplast. I- Kinetic and stoichiometry of fatty acids peroxidation. Arch. Biochem. Biophys. 125, 189-198.

Helena, M. de. and Carvalho, C. (2008) Drought stress and reactive oxygen species production, scavenging and signaling. Plant Signal and Behav. 3, 156-165.

Hepler, P.K. (2005) Calcium: A central regulator of plant growth and development. Plant Cell, 17, 2142-2155.

Hoagland, D.R. and Arnon, D.I. (1950) The water-culture method for growing plants without soil. Calif. Agric. Exp. Stn. Circ. 347, 1-32.

Horemans, N., Foyer, C.H. and Asard, H. (2000) Transport and action of ascorbate at the plant plasma membrane. Trends Plant Sci. 5, 263-267.

Hussain, T.M., Chandrasekhar, T., Hazara, M., Sultan, Z., Saleh, B. and Gopal, G.R. (2008) Recent advances in salt stress biology. Biotechnol. J. 3,1008-1013.

Itoi, T. and Lopaschuk, G.D. (1996) Calcium improves mechanical function and carbohydrate metabolism following ischemia in isolated bi-ventricular working hearts from immature rabbits. J. Mol. Cell. Cardiol. 28, 1501-1514.

Jindal, K.K. and Singh, R.N. (1975) Phenolic content in male and female Carica papaya: A possible 
physiological marker sex identification of vegetative seedlings. Physiol. Planta, 33, 104-107.

Kamisha, L.J., Moore, S.J., Owen, W.E., Cutler, J.M. and Frank, E.I. (2009) A rapid HPLC method used to establish pediatric reference intervals for vitamins A and E. Clinica Chimica Acta, 405, 35-38.

Kampfenkel, K., Montagu, M. and Van-Inze, De. (1995) Extraction and determination of ascorbate and dehydroascorbate from plant tissue. Anal Biochem. 225, 165-167.

Kanwal, S., Ashraf, M., Shahbaz, M. and Iqbal, M.Y. (2013) Influence of saline stress on growth, gas exchange mineral nutrients and non-enzymatic antioxidants in Vigna radiata L. Pak. J. Bot. 45(3), 763-771.

Kar, M. and Mishra, D. (1976) Catalase, peroxidase and polyphenol oxidase activities during rice leaf senescence. Plant Physiol. 57, 315.

Kaymakanova, M. (2012) Effects of salinity on germination and seed physiology in bean (Phaseolus vulgaris L.). Biotechnol Biotechnol Eq. 23, 326-329.

Khafagy, M.A., Arafa, A.A. and El-Banna, M.F. (2009) Glycinebetaine and ascorbic acid alleviate the harmful effects of $\mathrm{NaCl}$ salinity in sweet pepper, Australian J. Crop Sci. 3, 257-267.

Khan, T. A., Mazid, M. and Mohammed, F. (2011) A review of ascorbic acid potentialities against oxidative stress induced plant. J. Agrobiol. 28(2), 97-111.

Kibria, M.G., Hossaini, M., Murata, Y. and Hoque, A.Md. (2017) Antioxidant defense mechanisms of salinity tolerance in rice genotypes. Rice Science, 24(3), 155-162.

Kumari, N., Jain, V. and Talwar, G. (2013) Salinity induced changes in ascorbic acid, hydrogen peroxide, lipid peroxidation and glutathione content in leaves of salt tolerant and salt-susceptible cultivars of cotton (Gossypium hirsutum L.). Res. Plant Biol. 3, 6-11.

Lauchli, A. (1990) Calcium, salinity and plasma membrane. In: "Calcium in Plant Growth and Development" Leonard, R.J. and Hepler, P.K. (Ed.). 26: p. 35. The American Society of Plant Physiologists Rockville, M.D.

Lee, Y.P. and Takahashi, T. (1966). An improved calorimetric determination of amino acids with the use of ninhydrin. Anal. Biochem. 14,17.
Li, J.M, and Jin, H. (2007) Regulation of brassinosteroid signaling. Trends Plant Sci. 12(1), 37-41.

Lowry, O.H., Rosenbrough, J., Fan, A.C. and Randal, R.J. (1951) Protein measurements with Folin-phenol reagent. J. Biol. Chem. 193, 265-275.

Malvi, U.R. (2011) Interaction of micronutrients with major nutrients with special reference to potassium. Karnataka J. Agric. Sci. 24(1), 106-109.

Marklund, S. and Marklund, G. (1974) Involvement of the superoxide anion radicle in the antioxidant of pyrogallol and convenient assay for superoxide dismutase. Eur. J. Biochem. 74, 469-474.

Maxwell, D.P. and Batman, D.F. (1967) Changes in the activities of some oxidases in extracts of Rhizoctonia infected bean hypocotyls in relation to lesion maturation. Phytophath, 57, 132.

Meloni, D.A. and Martinez, C.A. (2009)Glycinebetaine improves salt tolerance in vinal (Prosopis ruscifolia Griesbach) seedlings. Brazilian J. Plant Physiol. 21, 233-241.

Mittler, R., Vanderauwera, S., Gollery, M., Breusegem, F. Van. and Van Breusegem, F. (2004) Reactive oxygen gene network of plants. Trends Plant Sci. 9, 490-498.

Munir, N. and Aftab, F. (2011) Enhancement of salt tolerance in sugarcane by ascorbic acid pretreatment. Afr. J. Biotechnol. 10, 18362-18370.

Munns, R. (2002) Comparative physiology of salt and water stress. Plant Cell Environ. 25, 239-250.

Naguib, M.I. (1964) Effect of sevin on the carbohydrate and nitrogen metabolism during germination of cotton seed. Indian J. Exp. Biol. 2, 149-152.

Naguib, M.I. (1969) Effect of nitrogen sources and/or colchicine on the colorimetry of nitrogen components of plant tissues. Bulletin of Faculty of Science, Cairo University, 43, 1-5.

Niakan, M. and Mazandrani, N. (2009) Allelopathic effects of Ascorbic acid and canola on germination and antioxidant enzyme activity in soybean seedlings. Allelop. J. 24, 283-290.

Niakan, M., Malekian, A. and Norinia, A. (2012) The effect of exogenous ascorbate and canola aquatic extracts on growth parameters and photosynthetic apparatus of soybean. Plant and Ecosyst. 7, 19-32.

Noctor, G. and Foyer, C.H. (1998) Ascorbate and glutathione: Keeping active oxygen under control. 
Annual Review of Plant Physiology and Plant Molecular Biology, 49, 249-279.

Othman, M.O.M. (2012) Alleviation of drought stress on Vigna radiate L. by using glycine betaine, proline or their Mixture. Dissertation Botany Department, Faculty of Science, Beni-Suef University, Egypt.

Parida, A.K. and Das, A.B. (2005) Salt tolerance and salinity effects on plants: A review. Ecotox. Environ. Safe. 60, 324-349.

Parihar, P., Singh, S., Singh, R., Singh, V.P. and Prasad, S.M. (2015) Effect of salinity stress on plants and its tolerance strategies: A review. Environ. Sci. Pollu. Res. Intern. 22, 4056-75. doi: 10.1007/s11356-0143739-1.

Pourcel, L., Routaboul, J.M., Cheynier, V., Lepiniec, L. and Debeaujon, I. (2007) Flavonoid oxidation in plants: From biochemical properties to physiological functions. Trends in Plant Sci. 12, 29-36.

Prajapati, K. and Modi, H.A. (2012) The importance of potassium in plant growth: A review. Indian J. Plant Sci. 1, 177-186.

Rafique, N., Raza, S.H., Qasim, M. and Iqbal, N. (2011) Pre-sowing application of ascorbic acid and salicylic acid to seed of pumpkin and seedling response to salt. Pak. J. Bot. 43, 2677-2682.

Rahdari, P., Tavakoli, S. and Hosseini, S.M. (2012) Studying of salinity stress effect on germination, proline, sugar, protein, lipid and chlorophyll content in Purslane (Portulaca oleraceae L.) leaves. Stress Physiol. Biol. J. 8(1), 182-193.

Ramesh, S.A., Choimes, S. and Schachtman, D.P. (2004) Overexpression of an Arabidopsis zinc transporter in Hordeum vulgare increases short-term zinc uptake after zinc deprivation and seed zinc content. Plant Mol. Biol. 54, 373-385.

Rekika, D., Nachit, M.M., Araus, J.L. and Monneveux, P. (1988) Effect of water deficit on photosynthetic rate and osmotic adjustment in tetraploid wheat. Photosynthetica, 35, 129-138.

Shabala, S. and Cuin, T.A. (2008) Potassium transport and plant salt tolerance. Physiol. Planta. 133, 651669.

Shahbaz, M., Noreen, N. and Perveen, S. (2013) Triacontanol modulates photosynthesis and osmoprotectants in canola (Brassica napus L.) under saline stress. J. Plant Interac. DOI:10.1080/174291 45.2013.764469.
Shann, J. and Blum, U. (1987) The uptake of ferulic and p-hydroxybenzoic acids by Cucumis sativus. Phytochemistry, 26, 2959-2964.

Sharma, P., Jha, A.B., Dubey, R.S. and Pessarakli, M. (2012) Reactive oxygen species, oxidative damage, and antioxidative defense mechanism in plants under stressful conditions. J. Bot. 2012, 1-26.

Siefermann, D. and Yamamoto, H.Y. (1974) Lightinduced de-epoxidation of violaxanthin in lettuce chloroplasts. III. Reaction kinetics and effect of light intensity on de-epoxidase activity and substrate availability. Biochim. Biophys.Acta, 357, 144-150.

Singh, T.N., Paleg, L.G. and Aspinall, D. (1973)Nitrogen metabolism and growth of barley plant during water stress. Aust. J. Biol. Sci. 26, 45-56.

Smirnoff, N. (1996) The function and metabolism of ascorbic acid in plants. Annals Bot. 78, 661-669.

Van Breusegem, F. and Dat, J.F. (2006) Reactive oxygen species in plant cell death. Plant Physiology, 141, 384-390.

Volkamar, K.M., Hu, Y. and Steppuhn, H. (1998) Physiological responses of plants to salinity: A review. Can. J. Plant Sci. 78, 19-27.

Wang, M., Zheng, Q., Shen, Q. and Guo, S. (2013) The critical role of potassium in plant stress response. Int. J. Mol. Sci. 14 (4), 7370-7390.

White, P.J. and Broadly, M.R. (2003) Calcium in plants. Annals Bot. 92, 487-511.

White, P.J. and Brown, P.H. (2010) Plant nutrition for sustainable development and global health. Ann. Bot. 105, 1073-1080.

Xu, J.B., Yuan, X.F. and Lang, P.Z. (1997) Determination of catalase inhibition by ultraviolet spectrophotometery. Chinese Environ Chem. 16, $73-76$.

Yamasaki, S. and Dillenburg, L.R. (1999)Measurement of leaf relative water content in Araucaria angustifolia. Revista Brasileira de Fisiologia Vegetal, 11, 69-75.

Yan, K., Shijie Zhao, S., Bian, L. and Chen, X. (2017) Saline stress enhanced accumulation of leaf phenolics in honeysuckle (Lonicera japonica Thunb.) without induction of oxidative stress. Plant Physiology and Biochemistry, 112, 326-334.

(Received 5/9/2017; accepted 19/11/2017) 


\section{التأثير التفاضلي لبعض الأسكوربات على نبات الفاصوليا (Phaseolus vulgaris L) في إستجابته للإجهاد الملحي لبعي الإني \\ بلر الاين عبد العال حامد و حمادة رجب عبده عبد الجواد

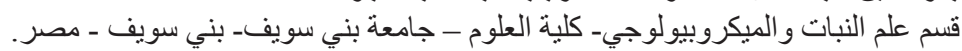

تهدف هذه الدر اسة إلى توضيح التأثير التفاضلي لأسكوربات البوتاسيوم وأسكوربات الكالسيوم على الإستجابة

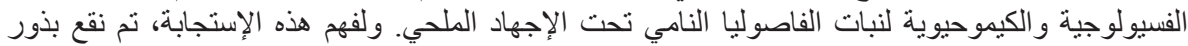

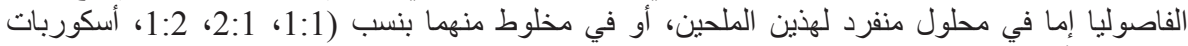

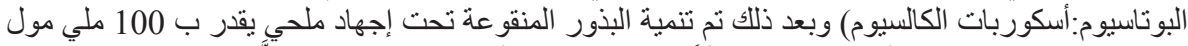

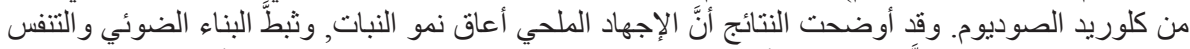

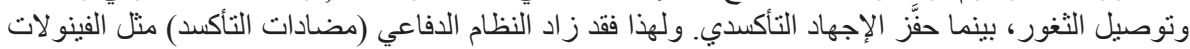

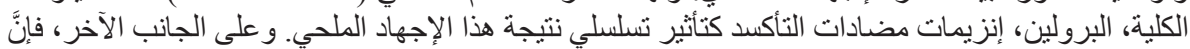

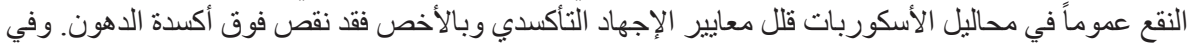

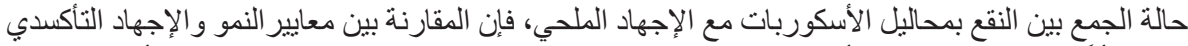

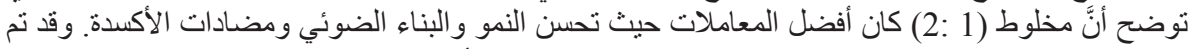
التوصل إلى هذه النتيجة بعد تحليل النتائج بنطبيق برنامج التحليل الأساسي (PCA). 